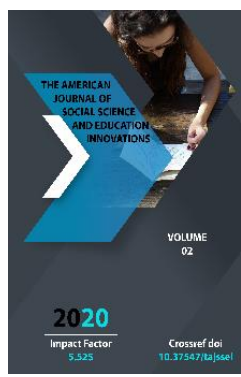

\title{
The Problem Of Religious Identity In The Youth Outlook
}

\author{
Dildora Dilshatovna Yusupova
}

Doctor Of Philosophy (PhD) In Philosophical Sciences, Acting Associate Professor, MilitaryTechnical Institute Of The National Guard Of The Republic Of Uzbekistan

Copyright: Original content from this work may be used under the terms of the creative commons attributes 4.0 licence.

\section{ABSTRACT}

The article explores the attempts of extremist groups under the guise of religion to use religion, especially Islam, to intimidate people with various weapons, and to gain and use the minds of young people through the Internet in order to inculcate their ideas and ideologies in the minds of young people in the age of globalization.

\section{KEYWORDS}

Religious identification, youth outlook, ideological immunity, value, atheistic ideology, globalization, stereotype, religion factor, religious belief.

\section{INTRODUCTION}

Today, there are a number of obstacles in the study of the problem of religious identification in Uzbekistan, one of which is the problems associated with the stereotypes and political mechanisms of the last century. For more than a century, the violation of the principles of religious beliefs and the complication of the policy of dependence have left their mark on the upbringing of the generation formed under the influence of the ideology of the former Soviet UnionAs a result, at the time of Uzbekistan's independence, the shallowness of traditions and values in the worldview of young people was clearly reflected in their 
ideological and spiritual emptiness. The return of religious values to Uzbekistan, which had been blocked during 130 years of colonial rule, has allowed various destructive ideologies and ideas to enter the region and harm the minds of young people.

A number of threats related to religion and the religious factor have emerged in Uzbekistan, and these threats have caused a number of problems internal political processes of our country. These threats (dogmatism, extremism) have not lost their relevance since the early days of independence. In this modern management of government, there are also difficulties in defining the relationship between religion and the state. Such processes are evident not only in Uzbekistan, but also in the Central Asian region.

Thanks to independence, the atheistic ideology was completely abandoned, and the ground was laid for the restoration of the Islamic religious values believed by our ancestors. In Uzbekistan, there has been an increase in religious beliefs, and along with the interest in Islam, non-traditional religious movements have begun to appear in the region. The growth of religious beliefs in our country was due to the destruction of the old system and the establishment of a new system, as well as the restoration of political structures. It is no secret that today, on the one hand, there is the issue of creating a democratic civil society free of legal and legal issues, and on the other hand, issues related to religious beliefs are waiting to be resolved.

After 130 years of dependence, the people of Uzbekistan are happy with the revival of Islam, the religion of their ancestors. And almost the majority of the population began to convert to Islam again. In June 1991, the pre- independence Law on Freedom of Conscience and Religious Organizations granted freedom of religion. The people, whose blood had been soaked in Islamic values, now began to believe in him freely and openly.

After gaining independence, our people, freed from the tyranny of the occupation, had to restore their language, religion, customs and traditions, to look to the future with a bright face, to feel proud of their ancestors. In the analysis of issues related to the factor of religion, along with the political processes that act as a bridge connecting the past and the present, the issue of religious situation, religious beliefs came to the fore. These problems are causing various disagreements not only among our citizens, but also in our internal policy. For example, the Law on Freedom of Conscience and Religious Organizations, adopted in 1991 and later amended in 1998, leaves open the issue of religious dress, which is currently the subject of controversy among school, high school, and university students. It is well known that the relationship between religion and the state is a very delicate matter and religion is a powerful factor that can influence the internal and external policy of the state. Therefore, religion can be separated from the state, but it cannot be separated from society.

When we look at the countries where Muslims live today, we see that they live not only on the laws of the country in which they live, but also on the laws of Sharia. But, unfortunately, many people today have a misconception about Islam, which leads to both internal and external conflicts. To end these conflicts, the study of the history of Islamic jurisprudence will play an important role in finding solutions to the challenges posed by the intensity of globalization. 
Today, the process of globalization is affecting the sphere of religion, as well as the whole sphere. In particular, the process of globalization serves as a ring for religious extremist groups to inculcate their ideas and ideologies in the minds of young people.

Under the banner of globalization, the desire to reform the world, to create religious conflicts, to propagate youth to religious extremist groups, and even to increase the number of hearth of religious extremism is seriously under scrutiny. It is no exaggeration to say that the use of religion, especially Islam, as a mask, the intimidation of people with various weapons, the capture and use of the Internet by young people is due to the intensity of globalization. Because the cause of globalization is the fact that some of our young people are victims of destructive ideas and are a weapon in the hands of extremist groups.

Unfortunately, there are also people in our society who are gaining strength from the intensity of globalization, trapping young people in the so-called "spider web" of the Internet and encouraging them to join religious extremist groups. People who have no knowledge of religion, its origins and essence, narrow-minded, spiritually poor people, especially young people, fall into their sphere of influence. It should be kept in mind that these actions are based on the interests of geopolitical forces seeking to take over the world.

It is known that young people are always inclined to receive news and information. If they do not receive information in a timely manner and their questions remain open, they will eventually have an ideological emtpiness.

At a time when the information crisis is on the rise, one of the main goals of religious extremist groups is to capture the minds of young people through the Internet and make them dependent on real life to virtual life. "If in the mid-1990s the favorite pastimes of young people were listening to music and watching television, today the computer and the Internet have squeezed out the previous interests from the lives of the younger generation" [1]. Indeed, in today's globalized world, the internet is a very powerful means of ideologically influencing the minds and emotions of young people, and it is becoming an integral part of life.

"Anyone can receive or transmit any information through the Internet, which surrounds the world today like a network," he said. Of course, without denying its importance in expanding people's worldview, knowledge and level, it is impossible to ignore the fact that through the same system there are pornographic sites that contradict simple moral norms, and transnational criminal groups, terrorists and fanatics use this modern information technology product. "[2]

We all know that in today's information age, the ability to receive and monitor religious or secular information from the Internet is expanding. However, there is a growing number of extremists who use it for various purposes and seek to sow discord among Muslims (Sunnis and Shiites). It is not for nothing that our wise people say that the way of work of such strange groups is "out of their minds." They want to achieve their goals by forming simple extremist and radical movements so that ordinary Muslims ... can unite with each other and not unite with each other. "[3]

Religious extremist groups are achieving their goals by capturing the minds of young people 
and making them dependent on them by creating various web pages where they can create opportunities for questions and answers and discussions. As a result, our young people, whose consciousness has not yet been formed, and whose religious education is shallow, are leaving their parents and homeland, going to other countries, joining extremist groups and throwing themselves into the abyss.

Religious extremists use the Internet for the following purposes:

advocacy to increase membership;

inculcating destructive ideas in the minds of young people under the guise of religion;

interfering in politics using the factor of religion and arousing protests among young people against the current state policy, etc.

Due to the variety of information available on the Internet today, it is difficult to tell which is right and which is wrong. There is no justification for religious extremists turning the pure ideas of Islam into their destructive ideas, using the Internet as a weapon to instill false information in the minds of young people, and turning many of our young people into manatees and using them as live bombs.

In particular, the holy book of Islam, the Qur'an, states: "And who is more unjust than he who forges a lie in the name of Allah? They will be confronted with their Lord, and the witnesses will say, "These are they who lied in the name of their Lord." Be aware that the Curse of Allah is for tyrants " [4], - warned. The verse describes the judgment about the Curse of the Lord on those who mislead people from the right path, and those who lie in the name of Allah.
In the context of globalization, one of the urgent tasks today is to form ideological immunity and educate young people to adhere to religious values in order to protect them from falling into the trap of religious extremist groups. In the words of President Shavkat Mirziyoyev: "It is the honorable duty of each of us to preserve and cherish our sacred religion, which embodies our ancient values and moral qualities. Islam means understanding the truth, it encourages people to do good deeds, calls each of us to goodness and peace, and teaches us to be real human beings. "[5]

In general, religious extremism is a reactionary idea that threatens the national and spiritual development of young people, undermines the principle of tolerance and paves the way for its collapse, while encouraging the use of Islam by their ancestors for evil purposes. It is the human duty of all of us to bring up young people in the spirit of devotion to national and religious values, to bring them up in a spiritually mature, strengthening their ideological immunity against various alien ideas, and being in the spirit of contribution to the development of our country.

In short, in the formation of ideological immunity against extremism and terrorism in young people, it is important to reveal the true intentions of extremist groups that seek to misinterpret the concepts of Islam, trying to poison the human mind and consciousness.

\section{REFERENCES}

1. Umarov B., Jabborov Sh. Problems of spiritual education in the context of globalization. -T .: -Akademiya, 2011. - Б. 57. 
2. Умаров Б. , Jabborov Sh. Globalization and spiritual and moral education. -T .: Akademiya, 2010. - 5. 24.

3. Appeal of world scholars. / Mansurov A. We have a word to say to our sincere people. Tashkent: Movarounnahr, 2016. - Б. 33.

4. Translation of the meanings of the Qur'an. Surah Hud. Translation and commentary by Abdulaziz Mansur. - Tashkent: Tashkent Islamic University, 2001. -B. 223.

5. Mirziyoev Sh.M. We will resolutely continue our path of national development and raise it to a new level. 1 year. / Education and enlightenment are the path to peace and creativity. -T .: "Uzbekistan", 2017. -B. 30. 